\title{
Minimum wages, earnings, and migration
}

\author{
Ernest Boffy-Ramirez
}

Correspondence:

econernest@gmail.com Department of Economics,

University of Colorado Denver, 1380 Lawrence Street, Suite 460 Denver, CO 80204, USA

\begin{abstract}
Does increasing a state's minimum wage induce migration into the state? Previous literature has shown mobility in response to welfare benefit differentials across states, yet few have examined the minimum wage as a cause of mobility. Focusing on low-skilled immigrants, this paper empirically examines the effect of minimum wages on location decisions within the United States. This paper expands upon minimum wage and immigration literatures by demonstrating that the choice of destination is sensitive to minimum wage changes, and that the effects are highly dependent on the number of years an immigrant has resided in the U.S.
\end{abstract}

JEL classification codes: J15, J61

Keywords: Migration; Minimum wages; Immigrants; Expected earnings

\section{Introduction}

Since at least the late 1960s, labor economists have attempted to measure the extent to which generous welfare benefits induce low-income individuals to migrate between states (Cebula 1979; Moffitt 1992). Of particular interest have been the location decisions of recent immigrants to the United States and their responsiveness to state-level welfare benefits (Borjas 1999). The extent to which immigrants move within the U.S. in response to such public benefit levels is clearly of importance to state and national policy makers, as well as economists aiming to better understand migration decisions.

At the same time, is it well known that the vast majority of working-age immigrants in the U.S. are employed and make-up a large share of the low-skilled labor force (Orrenius and Zavodny 2008). Thus, a full understanding of immigrants' location choices within the U.S. needs also to focus on the relative attractiveness of working in each state. Perhaps surprisingly, relatively little work has been conducted on the effects of exogenous changes in offered wages on the location decisions of immigrants within the U.S ${ }^{1}$. The purpose of this paper is to examine this question, by asking whether state-level minimum wage increases attract lower-educated immigrants to the states that enact them. Wages constitute a larger share of immigrant income when compared to welfare benefits, so the focus on expected earnings as a determinant of immigrant location is natural ${ }^{2}$. In addition, since recent immigrants are likely more mobile within the U.S. than natives are, immigrants are a straightforward choice for testing if minimum wage changes have any effect on labor migration decisions.

Using a panel of states, I estimate the effect of within-state changes in the minimum wage on state immigrant counts, taking into account key economic indicators in the

(C) 2013 Boffy-Ramirez; licensee Springer. This is an Open Access article distributed under the terms of the Creative Commons Attribution License (http://creativecommons.org/licenses/by/2.0), which permits unrestricted use, distribution, and reproduction in any medium, provided the original work is properly cited. 
calculation of expected earnings and controlling for state and national trends. Data on immigrant counts and wages comes from the 2000 5\% Census, the 2001-2007 American Community Surveys (ACS), and the Current Population Survey's Monthly Outgoing Rotation Groups (MORG) for the years 1994-2007.

Before I look at the effect of state minimum wage changes on immigrant counts, it is important to understand how this analysis differs from previous studies. Section 2 discusses the advantages of using immigrant samples and of using minimum wage increases. In Section 3, I establish the importance of the minimum wage for the earnings of low-skilled immigrants by estimating various specifications of hourly wages on minimum wage levels using the CPS MORG data. Similar to previous studies, I find robust evidence that minimum wages are a highly significant component of lowskilled immigrant earnings and that increasing the minimum wage does not significantly decrease immigrant employment. Together, these results indicate that higher minimum wages increase "expected" earnings, supporting the potential for a positive migration effect.

Section 4 explains how I measure immigrant counts. Since there is migration in and out of a state each year, immigrant counts reflect the difference between state inflows and outflows (the net flow) and will be referred to simply as the total "count". In Section 5, I present my estimation strategy for measuring the impact of minimum wage increases on immigrant mobility. I find that immigrants are mobile in response to minimum wage increases, but the effect is highly dependent on the number of years an immigrant has resided in the U.S. Low-skilled immigrants who have been in the U.S. for two to four years are mobile in response to changes in minimum wages. A fifty cent increase in a state's minimum wage is associated with up to a $13 \%$ increase in the number immigrants with two to four years in the U.S. While the percentage effect is large, after interpreting its magnitude relative to state counts and considering a number of other relevant factors, the induced migration varies dramatically across states. The results of the mobility analysis are confirmed using a number of robustness checks and extended to separately analyze immigrants from Latin America and Mexico exclusively.

In Section 7, I discuss why the number of years an immigrant has been in the U.S. is important, address potential concerns regarding endogeneity of the minimum wage, and present evidence supporting identification. I do not expect the effect of minimum wages on an immigrant's choice of state to be the same for recent and established immigrants. This paper suggests a migration scenario in which an immigrant is not most sensitive immediately upon arrival into the U.S., but is after a couple of years. In light of the fact that certain states have traditionally been hubs for new immigrants, it seems plausible that an individual arrives at a migration hub in the U.S. with information provided by a relative or a contact already in the U.S. The immigrant then reevaluates his or her present value of moving against that of staying using a new set of information better suited to analyze the different costs and benefits across states. Over time, as immigrants find a strong state match, set roots within a community, and accumulate human capital, the minimum wage is less binding and thus has little effect on their mobility decision.

In Section 8, I conclude by briefly discussing the policy implications of my results and potential extensions. 


\section{Immigration and magnets}

Previous studies of minimum wage effects have taken advantage of the minimum wage's greater prevalence among teenagers or service workers. In this paper, I will change the focus to a population which has received less attention in the minimum wage literature, that of immigrants. Immigrants are a useful choice of sub sample for a number of reasons. Recent immigrants have not yet developed strong attachments to particular localities. They are on average less educated than natives or established immigrants, tending to work in occupations where minimum wages bind ${ }^{3}$. Immigrants are not necessarily eligible for welfare, making them more focused on earnings opportunities ${ }^{4}$.

Contained within each migration decision are implicit evaluations of expected costs and benefits. Orrenius and Zavodny (2005) show that undocumented immigrant flows are highly responsive to changes in the returns to migration. They model the migration decision as a function of "push" and "pull" factors (those that cause people to leave a location versus those that attract them), finding that U.S. based pull factors are important to lower-skilled immigrants. This conclusion suggests a potential pull effect resulting from a minimum wage increase.

The concept of state-level income support policy attracting individuals is not new (Moffitt 1992) provides an overview of the early literature). Harris and Todaro's (1970) model of migration ties urban migration to expected wages as a function of minimum wages. In equilibrium, wage differentials should approach zero, yet distorted expectations of earnings and employment may incentivize rural workers to migrate to urban areas. Gelbach (2004) has asked whether differences in welfare generosity across states induce migration. Unlike previous work which finds small effects (Levine and Zimmerman 1999; Meyer 2000), Gelbach takes a sample of single mothers likely to receive welfare benefits, and finds significant mobility into high benefit states. Using a sample of single men without dependents in Norway, Fiva (2009) finds that after addressing welfare policy endogeneity due to cross-county welfare competition, the costs of benefit migration are significant.

Kennan and Walker (2010) use a sample of less-educated single mothers, but find that despite large differences in Aid to Families with Dependent Children (AFDC) benefits across states, the pull effect is weak. Income differentials appear to be a more important mobility incentive. Looking at adjacent counties with different AFDC separated by a state border, McKinnish $(2005,2007)$ finds a modest migration effect. Despite the potential for large effects, she concludes that welfare migration is probably not substantial given small existing cross-border differentials. This finding is similar to Bailey (2005), who also shows that while AFDC benefits did affect residential choice in the late 1980s, the effects are modest for $10 \%$ increases in benefit levels-particularly when considering most lowincome single mothers migrate to their state of birth regardless of the welfare benefit generosity.

Edmark (2009) looks at the migration effects of imposing job search, job training, or other work requirements as a condition for welfare benefit receipt within the context of the 1998 revision to the Social Services Act in Stockholm, Sweden. One expectation is that single mothers may move to another district within a municipality to avoid stipulations that increase the costs of being a welfare recipient. While benefit level are not different across districts, variation in the implementation of the welfare-work programs provides identifying variation. Edmark argues that the difference-in-difference-in-difference 
estimator is valid due to its ability to control for migration trends within districts. Edmark finds no evidence of migration (in or out migration) in response to changes in welfare benefit eligibility requirements.

A $10 \%$ increase in a state's benefit level is not associated with large increases in number of low-income single mother families receiving benefits according to Bailey (2005), but the costs of the benefits to these families accrue every year and can also increase as in-migration continues over time ${ }^{5}$. The size of the benefit increase is also crucial to estimating the budgetary impact on the state.

Borjas (1999) asks whether immigrants and female-headed households with children cluster into states which provide greater welfare benefits. Once the fixed costs of migration are internalized, he expects migrants will naturally gravitate to states where the expected value of earnings and benefits are higher. Using 1980 and 1990 household level Census data, Borjas takes advantage of variation in benefits across states and finds that not only does California act as magnet for immigrants, but it also attracts a disproportionate amount of lower-skilled workers. According to his model, low-skilled workers will cluster where benefits are high and the returns to skill are low, yet in many leading migration states, benefit levels were static as a percentage of the median state's benefits during the sample period.

One advantage of focusing on immigrants is that they are by definition mobile, and thus more likely to respond to income differentials. Despite evidence of clustering in Borjas' study, the importance of welfare benefits as the mechanism inducing migration is tenuous. As defined, welfare benefits may not account for non-monetary benefits like food stamps and it is probable that different types of people rely on different types of welfare benefits. In an earlier study, Borjas and Hilton (1996) show that participation rates for cash-benefit welfare programs are the same for immigrants and natives, but differ greatly for food stamps, Medicaid, and housing assistance. In addition, familiarizing oneself with state welfare policies and comparing benefits across states involves incurring substantial information costs, of which may be especially high for non-English speaking immigrants. Programs can take different forms and have different requirements, so including welfare benefits as a part of an implicit utility maximization calculation is nuanced.

This study makes an important distinction from the previous literature by focusing on minimum wages instead of welfare benefit differentials. Since the majority of immigrants work, wages (and minimum wages) are more likely to affect location decisions compared to welfare benefits. In contrast to the high informational costs associated with understanding each state's welfare system, knowledge of a state's minimum wage is accessible and is directly relevant to earnings.

\section{Immigrant earnings and minimum wages}

The connection between minimum wages and immigrant earnings has been previously established. Orrenius and Zavodny (2008) find that increases in the minimum wage positively effect on the hourly wages of less-skilled immigrant but do not find evidence of disemployment effects ${ }^{6}$. Using a an instrumental variables approach, Giulietti (forthcoming) also finds that minimum wage increases substantially increase the expected earnings of immigrants without significant disemployment effects. In related literature, Lee (1999) and DiNardo et al. (1996) find strong effects of minimum wages on wage distributions for the whole U.S. population. 
To establish the connection between immigrant earnings and the minimum wage in the context of this paper, I use hourly wage data from the Current Population Survey's Monthly Outgoing Rotation Groups (MORG) for the years 1994 through 2007. I run various regressions of hourly wages on state minimum wages, demographic and employment covariates, polynomials in age, state and year fixed effects, and state-specific linear time trends. Observations are persons ages 16-65, who have at most a high school degree or GED. Individuals are all foreign born non-citizens. Students and the self-employed are excluded.

In all specifications the minimum wage is significantly associated with hourly wages. Coefficients range from about 17 to 23 cents per dollar increase in the minimum wage ${ }^{7}$. The results of this estimation can be provided upon request. Using a similar 19942005 sample from the CPS MORG, Orrenius and Zavodny's (2008) estimates of the effect of real minimum wages on log real hourly earnings produce roughly similar values when converted into cents ${ }^{8}$. Narrowing my sample to the largest immigrant group, Latin Americans, or to workers younger than 25 years old yields larger estimates significant well beyond the $1 \%$ level $^{9}$.

\section{Measuring immigrant counts}

By increasing expected earnings, higher minimum wages have the potential to induce migration. To investigate immigrants by arrival year, I look to the $20005 \%$ Census and 2001-2007 American Community Surveys. Immigrants in my Census/ACS sample are defined using the same criteria as was used in the CPS MORG sample. The sample comprises persons ages 16-65 who have a high school degree or less, are foreign born, not self-employed, non-citizen, and are participating in the labor force (to separate those who are working or looking from those who have no intention of working). A comparison of the CPS and ACS samples is reported in Table $1^{10}$.

\section{Table 1 CPS and ACS comparison of observable characteristics}

\begin{tabular}{lcc}
\hline & CPS (1994-2007) & ACS (2000-2007) \\
\hline Average age (yrs) & 36 & 35 \\
Age 30 or less (\%) & 38 & 39 \\
Male (\%) & 64 & 64 \\
Live in metro area (\%) & 92 & 90 \\
Married (\%) & 54 & 48 \\
Never married (\%) & 30 & 32 \\
Spouse absent (\%) & 7 & 9 \\
No children (\%) & 70 & 51 \\
One child (\%) & 11 & 15 \\
12th grade (\%) & 40 & 43 \\
9th grade (\%) & 9 & 9 \\
5th or 6th grade (\%) & 18 & 17 \\
Latino (\%) & 66 & 75 \\
Born in Mexico (\%) & 46 & 56 \\
Construction† (\%) & 11 & 15 \\
Food service (\%) & 12 & 14 \\
Private sector (\%) & 98 & 93 \\
\hline Obs. & 96,776 & 484,917 \\
\hline
\end{tabular}

† The ACS uses NAICS industry codes while the CPS uses SIC Detailed Industry codes. 
Agricultural workers are removed because employment and pay follow seasonal trends unrelated to the minimum wage. Immigrant counts may include legal nonresidents, temporary workers, expected long-term residents, and unauthorized immigrants. Lastly, I group immigrants by the number of years they have been living in the United States. Collapsing immigrant counts into state-year cells, I get 408 observations (50 states over 8 years, plus the District of Columbia). An observation is the sum of all immigrants in a state that year, so it reflects the net of both inflows and outflows.

Lubotsky (2007) has shown that there is no precise way to determine how many times an immigrant has come to the U.S. before. The ACS asks the year when the individual arrived, but specifies that if the person has entered the U.S. more than once, to report the latest year he or she came to live in the U.S. If an immigrant has a set pattern of migration, it is unlikely that they will be responsive to differences in the minimum wage across states. On the other hand, a person who migrates often is footloose, and if sending remittances abroad is a priority, we may predict stronger sorting into states with large minimum wage increases. I address the implications of repeat migrants in a later discussion.

Migration to California and Texas together account for over $50 \%$ of the total count spanning the 8 year ACS sample, while the next four leading destination states together account for an additional $21 \%$. California consistently accounts for about $35 \%$ of the total. Table 2 lists the states that experienced changes in their minimum wage, the year they took effect, and the resulting wage. Between 2000 and 2006, there were 18 states with consequential changes in the minimum wage ${ }^{11}$.

State minimum wages are drawn from the Bureau of Labor Statistics' Wage and Hour Division. I replace a state's minimum wage with the federal minimum if the federal minimum is higher. In cases where the minimum wage takes on a range of values based on a firm's annual receipts (e.g. between 5.25 and 6.15 dollars in Minnesota), the lowest

Table 2 Minimum wage changes 2000 to 2006

\begin{tabular}{lcll}
\hline State & Changes & Year of change & Minimum wage after increase \\
\hline Alaska & 1 & 2003 & 7.15 \\
California & 2 & $2001-02$ & $6.25,6.75$ \\
Connecticut & 6 & $2000-04,2006$ & $6.15,6.40,6.70,6.90,7.10,7.40$ \\
Delaware & 2 & $2000-01$ & $5.65,6.15$ \\
District of Columbia & 2 & $2005-06$ & $6.50,6.90$ \\
Florida & 1 & 2006 & 6.40 \\
Hawaii & 3 & $2002-03,2006$ & $5.75,6.25,6.75$ \\
Illinois & 2 & $2004-05$ & $5.50,6.50$ \\
Maine & 4 & $2002-03,2005-06$ & $5.75,6.25,6.35,6.50$ \\
Massachusetts & 2 & $2000-01$ & $6.00,6.75$ \\
Minnesota & 1 & 2006 & 5.25 \\
New Jersey & 1 & 2006 & 6.15 \\
New York & 2 & $2000-06$ & $6.00,6.75$ \\
Oregon & 5 & $2000,2003-06$ & $6.50,6.90,7.05,7.25,7.50$ \\
Rhode Island & 3 & $2000-01,2004$ & $5.65,6.15,6.75$ \\
Vermont & 5 & $2000-01,2004-06$ & $5.75,6.25,6.75,7.00,7.25$ \\
Washington & 7 & $2000-06$ & $6.50,6.72,6.90,7.01,7.16,7.35,7.63$ \\
Wisconsin & 1 & 2006 & 5.70
\end{tabular}

Note-Table 2 contains changes used in the immigrant mobility analysis. These changes occurred between 2000 and 2006, so neither the state increases in 2007 nor the federal increase of 2007 is included. Illinois' two changes are not included in my preferred estimation. 
rate is used ${ }^{12}$. There are also two changes in Illinois' minimum wage which only apply to employers of at least four or more. Because the state rate does not apply consistently across all employees, I use the federal rate as the default measure. The addition of these two increases has little effect on the results though.

Data on real GDP per capita by state is from the Bureau of Economic Analysis and is chained to 2000 dollars. State unemployment rates are from the Bureau of Labor Statistics. To represent the value of possible earnings opportunities in non-minimum wage jobs, I calculate a measure of hourly wages in the manufacturing sector by dividing total salary and wage disbursements by total wage and salary employment using the most inclusive NAICS manufacturing classification ${ }^{13}$. A comparison of states that changed their minimum wage as those that did not is reported in Table 3.

\section{Estimation}

The decision to migrate must capture a state's economic conditions, migration networks, and social environment. My empirical model looks at an aggregation of individual migration outcomes and estimates the effect of minimum wage increases using a reduced form model, taking into account employment prospects and other economic indicators. Historical popularity, networks, and migrant tolerance are also important determinants of location choice. I will address these issues in my estimation by first including state-specific fixed effects and linear time trends, then expand on these issues with a few additional robustness checks.

The interaction of state changes in minimum wages with the federal minimum wage creates cross-state variation from which we can identify the effect of minimum wages. Unlike cross-sectional studies that use a single change (Card 1992a,b; Card and Krueger 1994; Katz and Krueger 1992; Neumark and Wascher 2000), my study exploits multiple changes. Dube et al. (2010) note that case studies of a single change can address immediate minimum wage effects, but cannot address whether effects occur with longer lags.

Table 3 ACS data means \& standard errors

\begin{tabular}{lcccc}
\hline & All states & With changes & Without changes & Difference \\
\hline Immigrant counts & & & & \\
& 130,388 & 220,278 & 85,444 & $134,834^{* * *}$ \\
Minimum wage & $(292,120)$ & $(440,326)$ & $(159,658)$ & $0.87^{* * *}$ \\
& 5.44 & 6.02 & 5.15 & $1.71^{* *}$ \\
State population & $(0.60)$ & $(0.75)$ & $(0.00)$ & 0.20 \\
(in millions) & 5.63 & 6.77 & 5.06 & \\
Unemp. rate (\%) & $(6.30)$ & $(8.85)$ & $(4.43)$ & $6,642^{* * *}$ \\
& 4.75 & 4.88 & 4.68 & $10,907^{* * *}$ \\
Manufacturing inc. & $(1.15)$ & $(1.27)$ & $(1.08)$ & \\
& 43,220 & 47,648 & $(6,495)$ & 31,840 \\
GDP per cap. & $(8,559)$ & $(10,323)$ & $(4,379)$ & 272 \\
\hline
\end{tabular}


Furthermore, the precision of standard errors is overstated because case studies treat individual observations as independent when they are in fact spatially correlated.

An important concern is the lag between a change in a minimum wage and its effect on migration. In my sample, I match minimum wages changes with the following year's immigrant counts. This lagging is done for in all years and for all covariates.

On the other hand, anticipation may also be a concern. If an immigrant anticipates a rate increase, they may arrive before a minimum wage increase occurs. In this case, anticipation would create attenuation bias. In related evidence, Allegretto et al. $(2010,2011)$ directly reject the possibility that firms anticipate minimum wage increases by reducing employment prior to the change. Using a distributed lag model covering a six year window around minimum wage changes, the lead estimates do not support the anticipation hypothesis. Furthermore, since 2001 a few states have begun indexing their minimum wage so that it is independent of contemporaneous economic conditions-also making it easier for firms to adjust. Their estimates are robust to the exclusion of the indexed minimum wage increases or the adding of a control for an indexed increase in the minimum wage.

Using a panel of states over the 8 year period, I estimate the effect of minimum wages on net immigrant counts by regressing the log of the number of immigrants in the state on the previous year's minimum wages and covariates ${ }^{14}$. The controls are annual statewide economic indicators that are likely to influence an immigrant's perception of a state-they are real GDP per capita chained on 2000 dollars, the unemployment rate, and the average manufacturing wage. Real GDP per capita is used as a rough measure of how much money an average person makes in a year. Average manufacturing wages are used to capture a salient lower-skilled alternative to minimum wage work, and will also indirectly incorporate fluctuations in the greater state economy at the expense of the other covariates' precision. The decision to migrate is not only based on how much one expects to earn, but also the likelihood of finding work, so I include the state unemployment rate. The lagged structure of the model reduces the possibility of reverse causality, but this is explicitly tested and rejected in later robustness checks. I do not expect the current year's immigration to influence the previous year's economic conditions.

Specifically, I estimate

$$
\ln \left(\text { imm }_{s, t}\right)=\alpha+\beta \text { minwage }_{s, t-1}+\lambda X_{s, t-1}+\gamma_{s}+\tau_{t}+\gamma_{s} t * I_{s}+\epsilon_{s, t}
$$

where $i m m$ represents the number of immigrants in state $s$ in year $t . \beta$ measures the average marginal effect of a nominal change in a state minimum wage on the percentage of immigrants in that state relative to the existing immigrant population. $X$ is the vector economic covariates. $\gamma$ and $\tau$ are state and year fixed effects respectively. Standard errors are clustered by state.

All specifications contain state fixed effects to remove unobserved state characteristics constant over time that affect immigration, and year fixed effects to remove national level immigration trends common to all states over the sample period. A state's established popularity with immigrants will be accounted for in the state fixed effect, but the changing popularity of traditional destination states and differential trends in state population growth suggest the inclusion of linear state-specific time trends. It is likely that immigration trends varied across states with differing minimum wage regimes during this period $^{15}$. The presence of differential inflation and cost of living increases across states 
necessitates the use of state-specific linear trends. Cost of living and inflation are positively correlated with the minimum wage and are likely to be negatively correlated with immigration, thus their exclusion attenuates estimates of equation (1).

How welcoming a state is to new immigrants is a slow moving norm, and over short time periods may be relatively constant. While this could produce a small amount of variation, the inclusion of the state fixed effects and the time trends should absorb this variation. My estimates will be biased upwards if we assume a state's welcoming nature induces migration to that state and that minimum wages are somehow correlated with the state's welcoming nature towards immigrants. Again, this bias requires a state's "friendliness" to vary non-linearly over the period in question. In a later set of robustness checks, I show that the percentage of low-skilled immigrants in a state does not appear to influence the minimum wage level.

It is important to note that this model is static in the sense that after immigrants and natives migrate, we do not observe changes in the returns to skill or feedback as a consequence of the new labor supply composition. This is a safer assumption in the short-run.

\section{Estimation results}

The results based on equation (1) are reported in Tables 4, 5 and 6 . Table 4 estimates the minimum wage effect based on the sample of all immigrants, Table 5 is based on a sample of immigrants from Latin America (excluding Mexican immigrants), and Table 6 is based on a sample which contains just Mexican immigrants. The specifications in each table vary the number of years an immigrant has been in the U.S. The intervals are used to identify which immigrants are more mobile in response to minimum wage increases.

The main mobility estimates are reported in Table 4. The first specification in Panel A captures the most recent immigrants-those who have reported being the U.S. for 2 years

Table 4 Effect of minimum wages on logged immigrant counts by year of arrival: All immigrants

\begin{tabular}{|c|c|c|c|c|c|}
\hline & \multicolumn{5}{|c|}{$\begin{array}{l}\text { All immigrants } \\
\text { Years in the U.S. }\end{array}$} \\
\hline & yrs $<2$ & $2<y r s<4$ & $4<y r s<6$ & $7<$ yrs $<9$ & $y r s>10$ \\
\hline \multirow[t]{2}{*}{ Minimum wage $_{t-1}$} & .165 & $.260^{* *}$ & .056 & -.007 & -.053 \\
\hline & $(.142)$ & $(.108)$ & $(.092)$ & $(.106)$ & $(.060)$ \\
\hline \multirow[t]{2}{*}{ GDP per capita $t-1(\times 1,000)$} & .060 & $.100^{*}$ & .074 & -.023 & .017 \\
\hline & $(.063)$ & $(.055)$ & $(.046)$ & $(.067)$ & $(.029)$ \\
\hline \multirow[t]{2}{*}{ Unemployment $_{t-1}$} & .048 & $.120^{*}$ & .028 & .093 & .035 \\
\hline & $(.079)$ & $(.071)$ & $(.066)$ & $(.086)$ & $(.038)$ \\
\hline \multirow[t]{2}{*}{ Manufacturing $_{t-1}(\times 1,000)$} & -.001 & .009 & -.013 & .026 & .000 \\
\hline & $(.021)$ & $(.019)$ & $(.013)$ & $(.020)$ & $(.007)$ \\
\hline State \& year FE & $\checkmark$ & $\checkmark$ & $\checkmark$ & $\checkmark$ & $\checkmark$ \\
\hline State trends & $\checkmark$ & $\checkmark$ & $\checkmark$ & $\checkmark$ & $\checkmark$ \\
\hline$R^{2}$ & .94 & .96 & .97 & .96 & .99 \\
\hline Obs. & 404 & 405 & 401 & 402 & 408 \\
\hline
\end{tabular}


Table 5 Effect of minimum wages on logged immigrant counts by year of arrival: Latin American immigrants

\begin{tabular}{|c|c|c|c|c|c|}
\hline & \multicolumn{5}{|c|}{$\begin{array}{c}\text { Latin American immigrants } \\
\text { Years in the U.S. }\end{array}$} \\
\hline & yrs $<2$ & $2<y r s<4$ & $4<\mathrm{yrs}<6$ & $7<$ yrs $<9$ & yrs $>10$ \\
\hline \multirow[t]{2}{*}{ Minimum wage $_{t-1}$} & -.016 & .038 & $.285^{*}$ & -.017 & $.159^{*}$ \\
\hline & $(.388)$ & $(.341)$ & $(.160)$ & $(.169)$ & $(.091)$ \\
\hline \multirow[t]{2}{*}{ GDP per capita ${ }_{t-1}(\times 1,000)$} & .116 & .155 & .006 & -.020 & -.007 \\
\hline & $(.134)$ & $(.120)$ & $(.083)$ & $(.089)$ & $(.064)$ \\
\hline \multirow{2}{*}{ Unemployment $_{t-1}$} & .176 & $.241^{*}$ & .169 & -.139 & .019 \\
\hline & $(.210)$ & $(.132)$ & $(.116)$ & $(.152)$ & $(.096)$ \\
\hline \multirow[t]{2}{*}{ Manufacturing $_{t-1}(\times 1,000)$} & -.008 & -.026 & -.012 & .026 & -.022 \\
\hline & $(.057)$ & $(.042)$ & $(.048)$ & $(.038)$ & $(.025)$ \\
\hline State \& year FE & $\checkmark$ & $\checkmark$ & $\checkmark$ & $\checkmark$ & $\checkmark$ \\
\hline State trends & $\checkmark$ & $\checkmark$ & $\checkmark$ & $\checkmark$ & $\checkmark$ \\
\hline$R^{2}$ & .88 & .90 & .92 & .91 & .95 \\
\hline Obs. & 325 & 347 & 340 & 319 & 377 \\
\hline
\end{tabular}

or less. For the most recent immigrants, the effect is not trivial in magnitude but indistinguishable from zero. In the second column, for immigrants with 2 to 4 years in the U.S., the coefficient on minimum wage is significant at the $5 \%$ level $^{16}$. Beyond this narrow window the effect dissipates. The last two specifications take immigrants who are relatively established, with either 7 to 9 or over 10 years in the U.S. I expect these immigrants to be less mobile, and thus less responsive to increases in the minimum wage. The last two columns suggest that as the length of residence in the U.S. increases, immigrants become insensitive to a state's minimum wage ${ }^{17}$.

Table 6 Effect of minimum wages on logged immigrant counts by year of arrival: Mexican immigrants

\begin{tabular}{|c|c|c|c|c|c|}
\hline & \multicolumn{5}{|c|}{$\begin{array}{l}\text { Mexican immigrants } \\
\text { Years in the U.S. }\end{array}$} \\
\hline & yrs $<2$ & $2<y r s<4$ & $4<y r s<6$ & $7<$ yrs $<9$ & yrs $>10$ \\
\hline \multirow[t]{2}{*}{ 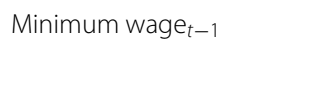 } & .054 & $.404^{* *}$ & .137 & -.327 & -.074 \\
\hline & $(.191)$ & (.192) & $(.187)$ & $(.269)$ & $(.207)$ \\
\hline \multirow[t]{2}{*}{ GDP per capita $t_{-1}(\times 1,000)$} & -.070 & .004 & -.067 & $-.144^{*}$ & .094 \\
\hline & $(.077)$ & $(.096)$ & $(.070)$ & $(.084)$ & $(.086)$ \\
\hline \multirow[t]{2}{*}{ Unemployment $_{t-1}$} & .002 & .050 & .146 & -.137 & -.041 \\
\hline & $(.105)$ & $(.109)$ & $(.141)$ & $(.121)$ & $(.101)$ \\
\hline \multirow[t]{2}{*}{ Manufacturing $_{t-1}(\times 1,000)$} & -.009 & .018 & -.011 & -.004 & .015 \\
\hline & $(.031)$ & $(.030)$ & $(.028)$ & $(.062)$ & $(.022)$ \\
\hline State \& Year FE & $\checkmark$ & $\checkmark$ & $\checkmark$ & $\checkmark$ & $\checkmark$ \\
\hline State trends & $\checkmark$ & $\checkmark$ & $\checkmark$ & $\checkmark$ & $\checkmark$ \\
\hline$R^{2}$ & .93 & .95 & .95 & .94 & .97 \\
\hline Obs. & 355 & 364 & 362 & 350 & 387 \\
\hline
\end{tabular}


For immigrants with 2 to 4 years in the U.S., the minimum wage is positively associated with immigrant counts and significant at the $5 \%$ level. A dollar increase in the minimum wage corresponds to a $26 \%$ increase in the number of less-educated immigrants with 2 to 4 years in the U.S. For California, in 2007 there were 224,885 less-educated immigrants in the labor force with 2 to 4 years in the U.S. out of a total state population of $36,553,215$. An increase of a dollar in California's minimum wage would increase the count by $26 \%$, so at 2007 population levels this increase represents 58,470 additional individuals. As a percentage of the entire low-skilled immigrant work force, this represents a $2.4 \%$ increase. Holding all else equal, if minimum wages remained unchanged across states, within 5 years an additional $26 \%$ compounded yearly would represent an additional 185,689 people.

In New Mexico, where the low-skilled immigrant share with 2 to 4 years in the U.S. totaled $0.37 \%$ of the state population in 2007 , the ratio would increase to $0.47 \%$ as a consequence of increasing the minimum wage by an entire dollar. An increase of $26 \%$ in the number of immigrants who have been in the U.S. 2 to 4 years is approximately 1,909 people. This implies a $3.2 \%$ increase the low-skilled immigrant work force. Holding all else constant, if I total each year's additional immigrants caused by the raised minimum wage over 5 years, the number comes out to 22,037 additional immigrants ${ }^{18}$.

Real GDP per capita and unemployment are significant at the $10 \%$ level in the second specification, but due to collinearity between the controls and the inclusion of fixed effects and time trends, the estimates are not precisely measured ${ }^{19}$. The measurement of these coefficients is not the aim of this paper. More importantly, since identification depends on the exogeneity of minimum wages, I examine collinearity between minimum wages and the controls. The specifications in Table 4 are estimated without any controls, only including the fixed effects and trends. I find that the estimated coefficients and significance of the minimum wage are very similar to the original specification, meaning that collinearity between the controls and the minimum wage is inconsequential and provides evidence of the exogeneity of minimum wage increases. These results are reported in Appendix 5.

Tables 5 and 6 restrict the immigrant sample to Latin Americans (excluding Mexicans), and solely Mexican immigrants, respectively. Interestingly, Latin Americans are sensitive to changes in the minimum wage after 4 to 6 years in the U.S. and beyond 10 years in the U.S., but these coefficients are marginally significant at the $10 \%$ level. Representing about $56 \%$ of the sample, it is clear that Mexican immigrants are driving the result for immigrants with 2 to 4 years in the U.S. from Table 4. According to Table 6, a dollar increase in the minimum wage is associated with $40.4 \%$ increase in the number of lesseducated Mexican immigrants with 2 to 4 years in the U.S., significant at the $5 \%$ level. The pattern of sensitivity to minimum wages for Mexican immigrants is stark, apparent in the spike between 2 and 4 years and dramatic drop-off in later years.

Concerned that the results are due to the specific construction of the arrival intervals, I perform a variety of alternate specifications changing the size of the groupings. My results are robust (though smaller in magnitude) when I group immigrants by either 1 to 5,1 to 6 , 2 to 5,2 to 6 , or 3 to 6 years in the U.S. All of these results contain the 2 to 4 year interval, and are summarized in Table 7. For the sample using all immigrants the coefficients are significant at either the $5 \%$ or $1 \%$ level, ranging between 11 and 21 percent $^{20}$. 
Below the results for all immigrants are the results using the Latin American and Mexican immigrant samples. For Latin Americans, the effects in Table 5 were only marginally significant. Widening the intervals reduces overall significance. For the sample of Mexican immigrants, the only significant effect reported in Table 6 was large but concentrated in a narrow interval. Averaging this result across a greater number of years reduces the coefficient's magnitude and also removes its significance. That said, the estimates remain large despite the wider interval.

Further isolating immigrants by single year of arrival shows that most of the observed effect is coming from immigrants with 2, 3, and 4 years in the U.S. Figures 1, 2, and 3 plot the coefficients estimated from equation (1) by single arrival year against number of years in the U.S. The estimates in the figures illustrate the sensitivity of minimum wage effect to an immigrant's arrival year, but it should be noted that using a single arrival year introduces additional imprecision to minimum wage estimates.

\section{Discussion \& identification}

The figures demonstrate that the effect of minimum wages on an immigrant's choice of state is not a monotonic function of how long the immigrant has resided in the U.S. The main results in Table 4 indicate that the most significant coefficients are those for immigrants who are relatively new and mobile, but who also have had time to adjust. This suggests a migration scenario in which an immigrant does not necessarily sort immediately upon arrival into the U.S., but rather moves after a brief period. This makes sense in light of the fact that certain states have traditionally been hubs for new immigrants. It is plausible that an individual arrives at a migration hub in the U.S. with information provided by a relative or a contact already in the U.S. The immigrant then reevaluates his or her present value of moving against that of staying with a new set of information. When immigrants sort after arrival instead of before, they are better suited to analyze the different costs and benefits across states. Over time, immigrants are less likely to move once they find a beneficial state match or set roots within a community. As an immigrant

Table 7 Effect of minimum wages on logged immigrant counts by year of arrival: Alternate arrival bin lengths

\begin{tabular}{|c|c|c|c|c|c|}
\hline & \multicolumn{5}{|c|}{ Years in the U.S. } \\
\hline & $1<$ yrs $<5$ & $1<$ yrs $<6$ & $2<$ yrs $<5$ & $2<$ yrs $<6$ & $3<$ yrs $<6$ \\
\hline \multirow[t]{2}{*}{ Minimum wage $_{t-1}$ (full sample) } & $.178^{* *}$ & $.110^{* *}$ & $.215^{* * *}$ & $.141^{* * *}$ & $.110^{* *}$ \\
\hline & $(.085)$ & $(.042)$ & $(.079)$ & $(.043)$ & $(.049)$ \\
\hline \multirow[t]{2}{*}{ Minimum wage $_{t-1}$ (Latin Am. sample) } & .086 & .189 & .068 & .199 & .158 \\
\hline & $(.344)$ & $(.301)$ & $(.388)$ & $(.315)$ & $(.282)$ \\
\hline \multirow[t]{2}{*}{ Minimum wage $_{t-1}$ (Mexican sample) } & .179 & .306 & .187 & .292 & .197 \\
\hline & $(.188)$ & $(.268)$ & $(.161)$ & $(.223)$ & $(.227)$ \\
\hline Economic controls & $\checkmark$ & $\checkmark$ & $\checkmark$ & $\checkmark$ & $\checkmark$ \\
\hline State \& year FE & $\checkmark$ & $\checkmark$ & $\checkmark$ & $\checkmark$ & $\checkmark$ \\
\hline State trends & $\checkmark$ & $\checkmark$ & $\checkmark$ & $\checkmark$ & $\checkmark$ \\
\hline Obs. in full sample & 407 & 407 & 406 & 406 & 403 \\
\hline Obs. in Latino sample & 363 & 368 & 357 & 362 & 356 \\
\hline Obs. in Mexican sample & 372 & 374 & 370 & 372 & 369 \\
\hline
\end{tabular}

Note-Standard errors are reported in parenthesis below the coefficients.* indicates significance at the $10 \%$ level, ${ }^{* *}$ at $5 \%$ level and ***at the $1 \%$ level. Standard errors are clustered by state. 


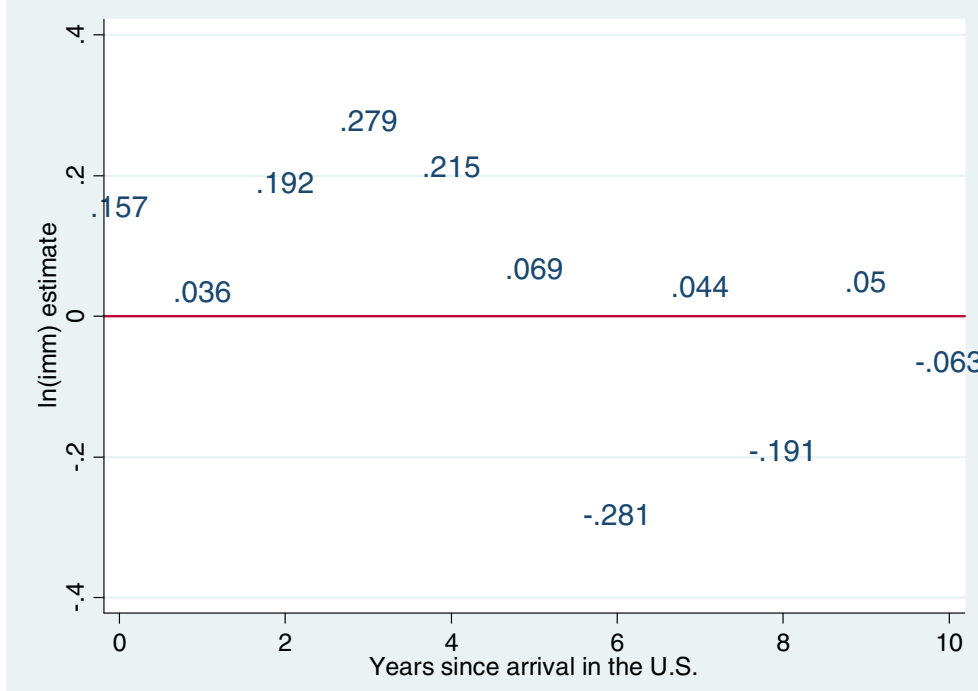

Figure 1 Marginal effect of a minimum wage increase by number of years in the U.S.: All immigrants.

accumulates human capital, increasing their wage, the importance of the minimum wage decreases.

This scenario is supported by Figure 1 where I plot the marginal effect of a minimum wage increase by number of years in the U.S. Splitting the arrival year groups into single arrival years reduces estimate precision, but we still see evidence indicating that the mobility effect is concentrated in the first years after arrival. The most recent immigrants are responsive to minimum wage increases but these coefficients are not distinguishable from zero. Only the coefficient pertaining to immigrants with exactly two years in the U.S. is significant. After four years in the U.S., the effect changes dramatically. This

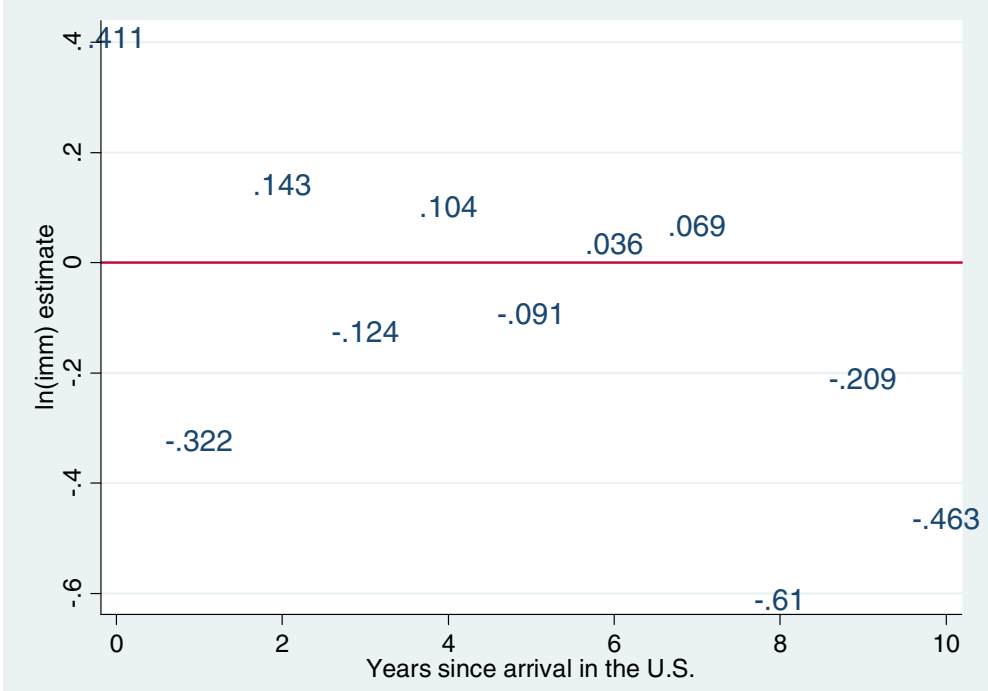

Figure 2 Marginal effect of a minimum wage increase by number of years in the U.S.: Latin American immigrants. 


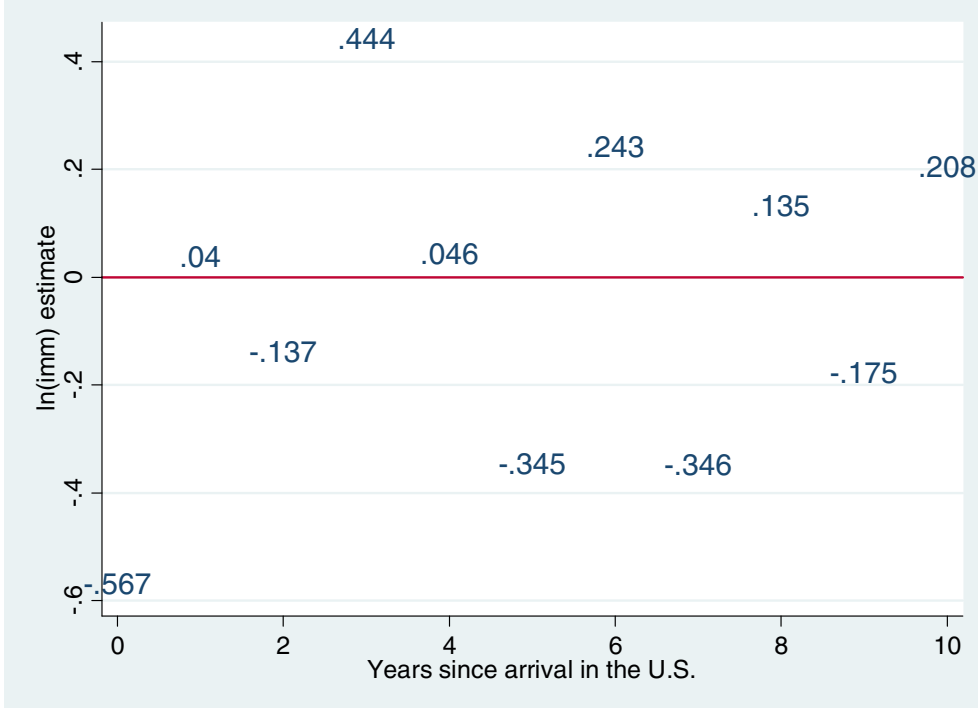

Figure 3 Marginal effect of a minimum wage increase by number of years in the U.S.: Mexican immigrants.

result is evidence that not separating immigrants by years of arrival will mask substantial heterogeneity in the effect of minimum wages on immigrant counts.

At first glance, these conclusions seemingly contradict those of Orrenius and Zavodny (2008). They claim low-skilled immigrants move out of states with minimum wage increases. Their outcome variable is the share of low-educated immigrants relative to the state population. The authors posit that when real log minimum wages increase, the fraction of less-educated adult (ages 20 to 54) immigrants in the population decreases. Using the same specification, they also find significant increases in the share of less-skilled natives.

Nevertheless, immigrant emigration is not required for there to be a decrease in the fraction of less-educated immigrants. To see this, note that the denominator is the state population. This includes the existing state population and new entrants-both native and non-native migrants. The numerator only contains the stock of low-skilled and newly arriving non-native migrants. As long as some natives are attracted to the state and these natives are on average more educated than immigrants (another of the paper's results), the fraction of low-skilled immigrants relative to the state population would decrease mechanically. As a consequence, the population will look less educated. This explanation is consistent with the results in Orrenius and Zavodny (2008), but it is also consistent with my results that claim a magnet effect. Given concurrent immigration and emigration, compositional changes in education could produce the same results ${ }^{21}$.

\subsection{Reverse causality}

Identifying the effect of a minimum wage increase on migration depends on the exogeneity of minimum wage increases, so we should be concerned about factors which may also induce migration that are not adequately accounted for. If these factors are correlated with the minimum wage my estimators will be biased. The hourly wages immigrants earn are strongly associated with the minimum wage, so it is possible that minimum wage legislation could also be affected by the number of low-skilled immigrants. For example, if 
immigration depresses wages, this may motivate an increase in the minimum wage. In another scenario, minimum wages could be responding to expected future immigration. I test for reverse causality and the possibility that increased immigration could influence minimum wage policy by conducting a falsification test using estimates from a linear probability model. The dependent variable is a binary variable indicating whether or not the minimum wage changed from the previous year, and is regressed on the log of the prior year's immigrant count. Specifically,

$$
\min \Delta_{s, t}=\alpha+\beta \ln \left(\mathrm{imm}_{s, t-1}\right)+\lambda X_{s, t-1}+\gamma_{s}+\tau_{t}+\gamma_{s} t * I_{s}+\epsilon_{s, t}
$$

where $\beta$ represents the estimated effect of the number of immigrants in the prior year on the probability of a state increasing its minimum wage ${ }^{22}$. The results are reported in Table 8. Specification (1) through (4) use a broader sample of low-skilled immigrant consisting of all person ages 16-65 who have a high school degree or less, are foreign born, and non-citizens. The labor force sample used in specification (5) through (8) is equivalent to the final sample from the mobility analysis.

Apart from the most basic specifications which only look at means, the average effect is negative regardless of whether we add leads for the economic covariates, state and year fixed effects, or state time trends. This negative relationship would imply that increasing immigration would decrease the probability of increasing the minimum wage, yet only specifications (3) and (7) prove to be significant. That noted, the extremely small magnitudes make the estimates economically insignificance. Taking the largest estimate in specification (3), a $1 \%$ increase in the low-skilled immigrant population is associated with .00231 decrease in the probability that the minimum wage increases.

It is not obvious that an influx of immigrants would shock the labor supply or generate immediate ripples in market wages and influence policy. Though it may be an underlying factor, common arguments against increases in the minimum wage have included job loss, labor substitution through outsourcing or mechanization, increased business costs, and higher prices to consumers. Factors cited as motivating minimum wage increases have included offsetting higher costs of living, raising standards of living, stimulating consumption, improving work ethic, and reducing wage inequality. From the results outlined

Table 8 Effect of logged immigration on the probability of a minimum wage increase

\begin{tabular}{lcccccccc}
\hline & \multicolumn{3}{c}{ Less-educated } & \multicolumn{5}{c}{ Labor force } \\
\cline { 2 - 9 } & $\mathbf{( 1 )}$ & $\mathbf{( 2 )}$ & $\mathbf{( 3 )}$ & $\mathbf{( 4 )}$ & $\mathbf{( 5 )}$ & $\mathbf{( 6 )}$ & $\mathbf{( 7 )}$ & $\mathbf{( 8 )}$ \\
\hline & & & & & & & & \\
In (immigrants $\left._{t-1}\right)$ & .005 & -.023 & $-.231^{* *}$ & -.138 & .003 & -.025 & $-.158^{*}$ & -.110 \\
& $(.020)$ & $(.023)$ & $(.115)$ & $(.128)$ & $(.020)$ & $(.023)$ & $(.082)$ & $(.086)$ \\
Economic controls $s_{t-1}$ & & $\checkmark$ & $\checkmark$ & $\checkmark$ & & $\checkmark$ & $\checkmark$ & $\checkmark$ \\
State \& year FE & & & $\checkmark$ & $\checkmark$ & & & $\checkmark$ & $\checkmark$ \\
State trends & & & & $\checkmark$ & & & & $\checkmark$ \\
\hline$R^{2}$ & .001 & .014 & .565 & .722 & .000 & .081 & .562 & .722 \\
Obs. & 306 & 306 & 306 & 306 & 306 & 306 & 306 & 306 \\
\hline
\end{tabular}

Note-Binary dependent variable is whether or not a state changed its minimum wage. Standard errors are reported in parenthesis below the coefficients. *indicates significance at the $10 \%$ level, **at $5 \%$ and ***at the $1 \%$ level. Standard errors are clustered by state. The lesseducated immigrant sample consists of all person ages 16-65 who have a high school degree or less, are foreign born, and non-citizens. The labor force sample is equivalent to the final sample from the mobility analysis. Specifically, they are the less-educated sample with additional restrictions to ensure that immigrants are in the labor force, not self-employed, not in unpaid work, and not working in the agricultural sector. Creating leads in immigration causes a reduction in the number of observations. 
in Table 8, it does not appear that immigration determines when a minimum wage will increase.

\subsection{Unobserved factors}

What about other factors that could be inducing migration that are correlated with the minimum wage and are not controlled for in equation (1)? In the following section, I discuss important sources of potential bias derived from omitted variables. The first source of bias concerns network ties, because having a strong network is likely to make that state attractive to an immigrant. Work by Deepti and Lang (2009) finds that increased network ties in Canada increase the flow of job offers an immigrant receives. Using a sample of Mexican immigrants, Munshi (2003) finds a positive relationship between network size, employment, and wages.

Networks are important determinants of migration, but it is less clear why networks would be correlated with minimum wage policy. From the analysis of minimum wage changes on the prior year's immigrant population, the immigrant stock is a variable related to network size but does not appear to be affecting minimum wage changes. State fixed effects will capture time invariant omitted factors which increase migration, and these include a state's historical role as a migration hub where networks are stronger. Network structures change slowly, but if the network structures do somehow change within the short 2000-2007 interval, the state specific linear trends may also pick up some of this variation.

If immigrants migrate in good economic times, minimum wages may be picking up some unobservable component about the good economy correlated with minimum wage increases. Previous work on this potential endogeneity has instrumented for minimum wage increases using the number congressional seats held by a particular political party $\left(\right.$ Lemos 2005) ${ }^{23}$. In my analysis, even with the inclusion of covariates which I argue summarize a state's economic conditions, state trends, and fixed effects, if some omitted factor is positively correlated with the minimum wage, I will overestimate the effect of an increase in the minimum wage on immigrant counts. The results of running equation (1) without controls, shows that the effect is robust to their exclusion-indicating that the minimum wage is not highly associated with broad measures of the state's economy. The confounding omitted factor must therefore meet a series of requirements in order to bias my estimates away from zero. The omitted variable must be positively correlated with minimum wages, it must attract immigrants, it must be uncorrelated with the economic covariates, and it must be changing non-linearly during the sample $\operatorname{period}^{24}$.

Two studies indicate that minimum wages actually increase during worsening or neutral economic conditions. This would imply either a negative correlation or zero correlation between minimum wages and immigration. A negative correlation has the effect of attenuating my estimates. Using various dynamic specifications with leads and lags, Allegretto et al. $(2010,2011)$ test to see if differential preexisting state trends are responsible for the minimum wage effects on employment. Estimating a distributed lag model with and without a set of spatial and time controls, they track the effect of a minimum wage change over time and find that minimum wages have tended to change during periods and in places with unusually low teen employment growth. With their preferred specification, there appears to be no pre-trend. Reich (2010) shows that while minimum 
wage increases are often passed during expansionary period with low unemployment, they are implemented in contractionary periods with unemployment growth ${ }^{25}$.

\subsection{Other issues}

This study only considers how foreign born individuals respond to minimum wages within the U.S. It is not clear if natives face the same decision as immigrants since we cannot assume mobility ex-ante as we did with immigrants. If natives are sufficiently mobile and respond to minimum wages as they do to welfare benefit differentials, this would further add to the magnet effect. This question is the focus of future research.

Lastly, there is concern about miscategorizing an immigrant's arrival year. Lubotsky (2007) shows that a significant portion of the immigrant population migrates back and forth, not allowing us to accurately measure immigrant composition. Suppose there are three types of immigrants, recent ones, long-term ones, and "churners" who migrate back and forth. If churners behave like recent immigrants with respect to minimum wages, they would appear in the results appropriately classified as recent immigrants. In fact, churners may be the most sensitive given their tendency to move often. If churners are actually similar to longer-term immigrants in terms of their accumulated skills, then this would create attenuation bias in my 2 to 4 year estimate. This is due to being categorized as recent immigrants when in fact they are not, and since they are insensitive to the minimum wage, their inclusion will reduce the average effect within the 2 to 4 year arrival grouping ${ }^{26}$.

\section{Conclusion}

Previous studies, such as Gelbach (2004), Borjas (1999), McKinnish (2005), and Fiva (2009), have found that differentials in welfare benefits can influence migration. Basic static models of labor supply suggest that the increases in the minimum wage would cause unemployment, and this could repel immigrants from migrating to that state. Instead, my paper shows that this explanation is not nuanced enough to account for what is seen in the data. First, consistent with previous literature by Orrenius and Zavodny (2008) and Giulietti (forthcoming), I find no disemployment effects and sizable hourly wage effects. Together, these results indicate that higher minimum wages increase expected earnings. Second, for a narrow group of immigrants, a higher expected wage attracts low-educated workers to that state. Using the minimum wage's close linkage with a less-educated worker's expected income, I find that in addition to being an important component of wages, a minimum wage increase can induce migration. This study's conclusion corroborates recent work by Giulietti (forthcoming), who finds that immigrants are more likely to settle in states that have high minimum wages. I find significant effects for immigrants who have been in the U.S. between two and four years. Within this window, a dollar increase in the minimum wage is associated with up to a $26 \%$ increase in immigrant counts. This result is robust to different specifications and persists despite changing the arrival interval. I find insignificant results for the most recent arrivals and those who have been in the U.S. over four years.

To put the magnitude of the effect into perspective, we must consider three points. First, coefficients varied between 11 and $26 \%$ depending on the subsample. Secondly, though $26 \%$ is a large percentage relative to the existing immigrant population within 
that same arrival grouping, when converted into person counts the numbers vary dramatically across states as seen in the cases of California and New Mexico. That said, it is important to recognize that even increases of $2 \%$ in the low-skilled immigrant work force may be important to those who could be seen a competitors in the labor market. Thirdly, minimum wage increases of one dollar are less common over the sample period (the average increase is 25 cents), meaning there is less reason to expect sharp spikes in migrant inflows. Nonetheless, abstracting from feedback or general equilibrium effects, if differentials are large and persistent year after year the cumulative effect becomes very large. To effectively make conclusions about the longer-term implications of minimum wage increases on mobility, we would then need to account for migration's effect on policy, wages, and labor market over time. Gelbach (2004) doesn't find evidence of this in his sample using AFDC benefits, yet it remains to be tested in mine.

The policy implications of raising minimum wages are twofold. The magnet effect depends on the size of the minimum wage increase and the size of the existing lesseducated immigrant population. Concerning natives, this result implies that the consequences of increased immigration, including displacement, are potentially relevant to natives within the same skill level (Peri and Sparber 2009). Similar to previous work, this study finds that raising the minimum wage has a positive effect on immigrant wages. At the same time, it appears to not have a significant effect on employment. Using CPS data, probit estimates of employment on the minimum wage, a large set of demographic covariates, state fixed effects, and state time trends, reveal that the effect of the minimum wage increases on employment cannot be distinguished from zero. When coupled with the fact that less-educated immigrants are highly affected by minimum wage increases and are more mobile than teens or single mothers, this paper suggests that the disemployment effects due to cross-border migration are also small. These results warrant additional research to investigate the potential employment effects on immigrants and natives.

\section{Endnotes}

${ }^{1}$ Orrenius and Zavodny (2008), Cadena (2012), and Giulietti (forthcoming) are the only studies to date that discuss immigrant mobility as a consequence of minimum wage increases.

${ }^{2}$ Many immigrants' reluctance to identify themselves, in addition to legislation that restricts access to benefits, casts doubt on the relevance of using welfare benefits (e.g. The Personal Responsibility and Work Opportunity Reconciliation Act of 1996). Attempts to make residency a requirement for benefit eligibility adds to this concern (e.g. Saenz v. Roe 1999; Maldonado v. Houston 1997).

${ }^{3}$ Orrenius, Zavodny, and Lukens (2008) find that the percentage of immigrants in agricultural occupations has been steadily declining over time, while sectors legally bound by minimum wage law, like service and sales, have been growing.

${ }^{4}$ The Personal Responsibility and Work Opportunity Reconciliation Act of 1996 restricted immigrant access to many welfare benefit services.

${ }^{5}$ The overall increase in participation is the sum of new in-state recipients and new migrant recipients, yet as some states experience in-migration, others will experience out-migration reducing their costs.

${ }^{6}$ For a $10 \%$ increase in the minimum wage, immigrant hourly earnings rise by $1.62 \%$ for men and $1.58 \%$ for women when controls for the business cycle are included.

${ }^{7}$ Using log hourly wages instead hourly wages produces semi-elasticities, that when converted into cents, are similar to the estimates from the original specification. 
${ }^{8}$ In a separate analysis, I run an extensive set of specfications estimating the effect of minimum wage increases on the probability of being employed. The resulting estimates show no evidence of disemployment effects. These tables can be provided upon request.

${ }^{9}$ As a falsification test, I also run specifications looking at the effect of minimum wage increases on the hourly wages of agricultural workers. Coefficients are consistently negative, small, and no effect is significant. Probit estimates of employment in agriculture on minimum wage changes provides some evidence that increases in the minimum may push low-skilled workers into the agricultural sector-but results are mixed. These results are reported in Appendices 1 and 2.

${ }^{10}$ Restricting the sample years to 2000-2007 produces very comparable samples. This comparison is reported in Appendix 3.

${ }^{11}$ The 2007 mid-year federal minimum wage increase and 2007 state increases in Michigan, Delaware, Maine, New Jersey, and Arkansas, are not included. The ACS sample covers up to 2007, but my specification relies on minimum wage changes from the previous year, so the last minimum wages that are accounted for are in 2006. In a few cases, state minimum wages changed in July or after. The ACS finishes surveying in June so the migration associated with these increases does not contaminate the present year's count.

${ }^{12}$ There are only three state-year observations which fall under this condition. Results are robust to using the higher of the rates.

${ }^{13}$ NAICS codes SA07N and SA270. Measures contain both full and part-time workers.

${ }^{14}$ Because the effect of minimum wage increases on the number of immigrants is likely proportional to a state's size, I account for the differential treatment of minimum wages by taking the log of the state counts. This allows me to interpret the coefficient as a percentage of a state's baseline immigrant population. Appendix 4 reports the results from an alternative log-log specification. These results are similar to those from the semi-log specification.

${ }^{15}$ Linear state trends will deal with differential trends in each state's native population over time, yet I also explicitly control for the total state population in an alternate specification. Results are only slightly affected by its inclusion-the coefficients on the minimum wage are reduced between one to four tenths of a percent.

${ }^{16}$ Using a sample which adds immigrants who are not in the labor force, I still find that increases in the minimum wage induce migration. Though as expected, magnitudes are smaller, and the coefficient on the 2 to 4 year specification is significant at the $10 \%$ level.

${ }^{17}$ Using a sample of low-skilled immigrants from the 1994-2007 CPS, Cadena (2012) finds immigrants move away from states that increase their minimum wage. He credits the decrease in immigration to disemployment effects induced by the change. Corroborating this study, he also finds that recent immigrants are the most sensitive to changes in the minimum wage. Despite using a slightly different sample, if I group all immigrants with less than 10 years in the U.S. and run a similar log-log specification without lags, I get negative elasticities of similar magnitude $(-.5,-.4)$ that are marginally significant at the $10 \%$ level.

${ }^{18}$ One may be concerned about the inclusion of Alaska and Hawaii's minimum wage changes due to their geographic remoteness. Since the effect is identified off the changers, removing these two states attenuates the estimates. For immigrants with 2 to 4 years in the U.S. we still see significance at the 5 percent (albeit weaker) but the coefficient drops to .192 .

${ }^{19}$ If migration decisions are formulated based on expectations and not actual earnings or employment realities, high unemployment rates do not necessarily deter migration (Harris and Todaro 1970). Furthermore, Table 3 indicates that there is not a significant difference in the unemployment rate of states that increased their minimum and those that did not. 


\begin{abstract}
${ }^{20}$ Estimates using only the states who experienced a minimum wage change drastically reduces the sample to a mere 134 observations and removes useful variation, but the key results from Table 4 still hold. For immigrants with 2 to 4 years in the U.S., a dollar increase in the minimum wage corresponds to a $29 \%$ increase in the flow of immigrants also significant at the $5 \%$ level. Removing Alaska and Hawaii has effects similar to those discussed earlier, but the coefficient is now significant at the $10 \%$ level.

${ }^{21}$ They suggest that out migration masks the true unemployment effect. While one possible mechanism, this hypothesis is not directly tested.

${ }^{22}$ Specifications with an additional lead in immigration were also tested, but had no economically or statistically meaningful differences compared to the model with a single lead.

${ }^{23}$ Using state congressional majorities as an instrument for minimum wage increases cannot account for national level increases in the minimum wage though. Furthermore, some state changes are pegged to inflation.

${ }^{24}$ If some states are known to have sanctuary cities that follow certain practices that encourage immigration, these states could be driving the migration results. Estimating equation (1) on a set of "non-sanctuary states" (states without cities that contain the high concentrations of immigrants), the results mirror the results in Table 4. According to this analysis, historically important destination states cannot be solely responsible for the migration effects. These results are reported in Appendix 6.

${ }^{25}$ For example, The Fair Minimum Wage Act of 2007 was implemented in July 2008 and July 2009.

${ }^{26}$ To minimize the potential effects of churning, I take a sample of immigrants from countries that consistently sent large shares of refugees to the U.S. between 2000 and 2007. Not all immigrants from these countries were refugees, but they are, on average, less likely to return migrate. Estimating equation (1) by year of arrival for just the sample of "refugees" produces results very similar to those in Table 4.
\end{abstract}

\title{
Appendix 1
}

OLS estimates of agricultural workers' wages on the minimum wage

\begin{tabular}{|lccccc|}
\hline & $(1)$ & $(2)$ & $(3)$ & $(4)$ & $(5)$ \\
\cline { 2 - 6 } & & & & \\
& & & & \\
& & & & \\
& .083 & -.097 & -.032 & -.033 & -.063 \\
& $(.080)$ & $(.093)$ & $(.092)$ & $(.094)$ \\
Demographic & $\checkmark$ & $\checkmark$ & $\checkmark$ & $\checkmark$ & $\checkmark$ \\
Family & & $\checkmark$ & $\checkmark$ & $\checkmark$ & $\checkmark$ \\
Employment & & & $\checkmark$ & $\checkmark$ & $\checkmark$ \\
Age polynomials & & & & $\checkmark$ & $\checkmark$ \\
State \& year FE & $\checkmark$ & $\checkmark$ & $\checkmark$ & $\checkmark$ & $\checkmark$ \\
State time trend & & & & & $\checkmark$ \\
Obs. & 5,281 & 5,281 & 4,853 & 4,853 & 4,853 \\
\hline
\end{tabular}

Note-Observations are individuals in state $\mathrm{s}$ and year $\mathrm{t}$. Standard errors are reported in parenthesis below the coefficients. ${ }^{* *}$ indicates significance at the $5 \%$ and ${ }^{* * *}$ at the $1 \%$ level. Observations are weighted using CPS weights and standard errors are clustered by state.c 


\section{Appendix 2}

Probit estimates of agricultural employment on changes in the minimum wage

\begin{tabular}{|lcccc|}
\hline & $(1)$ & $(2)$ & $(3)$ & $(4)$ \\
\cline { 2 - 5 } Minimum wage & $.007^{* * *}$ & $.086^{* * *}$ & $.082^{* * *}$ & $-.089^{* * *}$ \\
& $(.026)$ & $(.027)$ & $(.027)$ & $(.031)$ \\
Demographic & & $\checkmark$ & $\checkmark$ & $\checkmark$ \\
Family & & & $\checkmark$ & $\checkmark$ \\
Age polynomials & & & & $\checkmark$ \\
State \& year FE & $\checkmark$ & $\checkmark$ & $\checkmark$ & $\checkmark$ \\
State time trend & & & & $\checkmark$ \\
Obs. & 109,322 & 96,910 & 96,910 & 96,910 \\
\hline
\end{tabular}

Note-Estimates are in log-odds units. Observations are individuals in state $\mathrm{s}$ in year $\mathrm{t}$. Standard errors are reported in parenthesis below the coefficients.** indicates significance at the $5 \%$ and ${ }^{* * *}$ at the $1 \%$ level. All specifications contain state and year fixed effects, with observations weighted using CPS weights and standard errors are clustered by state. Economic covariates are not included in this set of regressions. Immigrants who earn no wage are included.

\section{Appendix 3}

CPS and ACS comparison, 2000-2007

\begin{tabular}{|lccc|}
\hline & CPS & & ACS \\
Average age (yrs) & 36 & & 35 \\
Age 30 or less (\%) & 38 & & 39 \\
Male (\%) & 65 & & 64 \\
Live in metro area (\%) & 92 & & 90 \\
Married (\%) & 52 & & 48 \\
Never married (\%) & 31 & & 32 \\
Spouse absent (\%) & 7 & & 9 \\
No children (\%) & 55 & & 51 \\
One child (\%) & 17 & & 15 \\
12th grade (\%) & 40 & & 43 \\
9th grade (\%) & 9 & & 9 \\
5th or 6th grade (\%) & 18 & & 17 \\
Latino (\%) & 65 & & 75 \\
Born in Mexico (\%) & 45 & & 56 \\
Private sector work (\%) & 98 & & 93 \\
${ } }$ & 61,856 & & 484,917 \\
\hline
\end{tabular}

Note-The occupational comparison is excluded. Workers in the ACS include active job seekers while the CPS does not. 


\section{Appendix 4}

Effect of logged minimum wages on logged immigrant counts by year of arrival

\begin{tabular}{|c|c|c|c|c|c|}
\hline & \multicolumn{4}{|c|}{ Years in U.S. } & \multirow[b]{2}{*}{$\mathrm{yrs}>10$} \\
\hline & $\mathrm{yrs}<2$ & $2<\operatorname{yrs}<4$ & $4<\operatorname{yrs}<6$ & $7<\mathrm{yrs}<9$ & \\
\hline $\log \left(\right.$ minimum wage $\left._{t-1}\right)$ & $\begin{array}{c}.943 \\
(.788)\end{array}$ & $\begin{array}{c}1.529^{* *} \\
(.634)\end{array}$ & $\begin{array}{c}.408 \\
(.509)\end{array}$ & $\begin{array}{c}.088 \\
(.696)\end{array}$ & $\begin{array}{l}-.258 \\
(.330)\end{array}$ \\
\hline GDP per capita $t-1(\mathrm{x} 1,000)$ & $\begin{array}{c}.060 \\
(.063)\end{array}$ & $\begin{array}{l}.099 * \\
(.055)\end{array}$ & $\begin{array}{c}.074 \\
(.046)\end{array}$ & $\begin{array}{l}-.023 \\
(.067)\end{array}$ & $\begin{array}{c}.017 \\
(.029)\end{array}$ \\
\hline Unemployment $_{t-1}$ & $\begin{array}{c}.049 \\
(.079)\end{array}$ & $\begin{array}{l}.121^{*} \\
(.072)\end{array}$ & $\begin{array}{c}.028 \\
(.066)\end{array}$ & $\begin{array}{c}.093 \\
(.086)\end{array}$ & $\begin{array}{c}.034 \\
(.038)\end{array}$ \\
\hline Manufacturing $_{t-1}(\mathrm{x} 1,000)$ & $\begin{array}{l}-.001 \\
(.021)\end{array}$ & $\begin{array}{c}.009 \\
(.019)\end{array}$ & $\begin{array}{l}-.013 \\
(.013)\end{array}$ & $\begin{array}{c}.026 \\
(.020)\end{array}$ & $\begin{array}{c}.000 \\
(.007)\end{array}$ \\
\hline State \& year FE & $\checkmark$ & $\checkmark$ & $\checkmark$ & $\checkmark$ & $\checkmark$ \\
\hline State trends & $\checkmark$ & $\checkmark$ & $\checkmark$ & $\checkmark$ & $\checkmark$ \\
\hline $\mathrm{R}^{2}$ & .94 & .96 & .97 & .96 & .99 \\
\hline Obs. & 404 & 405 & 401 & 402 & 408 \\
\hline
\end{tabular}

Note-Standard errors are reported in parenthesis below the coefficients. ${ }^{*}$ indicates significance at the $10 \%$ level, ${ }^{* *}$ at $5 \%$ and ${ }^{* * *}$ at the $1 \%$ level. Standard errors are clustered by state. Sample sizes vary slightly because we do not observe migrants in all state-year cells when the sample is stratified by arrival intervals.

\section{Appendix 5}

Effect of minimum wages on immigrant counts without controls

\begin{tabular}{|lccccc|}
\hline & & \multicolumn{4}{c}{ Year of arrival } \\
\cline { 2 - 5 } & yrs $<2$ & $2<\mathrm{yrs}<4$ & $4<\mathrm{yrs}<6$ & $7<\mathrm{yrs}<9$ & yrs $>10$ \\
\cline { 2 - 5 } Minimum wage $t-1$ & .173 & $.278^{* *}$ & .063 & .000 & -.047 \\
& $(.144)$ & $(.109)$ & $(.094)$ & $(.113)$ & $(.057)$ \\
State \& year FE & $\checkmark$ & $\checkmark$ & $\checkmark$ & $\checkmark$ & $\checkmark$ \\
State trends & $\checkmark$ & $\checkmark$ & $\checkmark$ & $\checkmark$ & $\checkmark$ \\
$\mathrm{R}^{2}$ & .94 & .96 & .97 & .96 & .99 \\
Obs. & 404 & 405 & 401 & 402 & 408 \\
\hline
\end{tabular}

Note-Standard errors are reported in parenthesis below the coefficients. ${ }^{*}$ indicates significance at the $10 \%$ level, ${ }^{* *}$ at $5 \%$ and ${ }^{* * *}$ at the $1 \%$ level. Standard errors are clustered by state. Sample sizes vary slightly due to not observing immigration in all state-year cell for each arrival interval. 


\section{Appendix 6}

Effect of minimum wages on logged immigrant counts by year of arrival for non-sanctuary states

\begin{tabular}{|lccccc|}
\hline & & \multicolumn{4}{c}{ Years in U.S. } \\
\cline { 2 - 5 } & $\mathrm{yrs}<2$ & $2<\mathrm{yrs}<4$ & $4<\mathrm{yrs}<6$ & $7<\mathrm{yrs}<9$ & yrs $>10$ \\
\cline { 2 - 5 } Minimum wage & & & & & \\
& .254 & $.399^{* * *}$ & .025 & .038 & -.088 \\
Economic covariates & $.216)$ & $(.141)$ & $(.140)$ & $(.164)$ & $(.092)$ \\
State \& year FE & $\checkmark$ & $\checkmark$ & $\checkmark$ & $\checkmark$ & $\checkmark$ \\
State trends & $\checkmark$ & $\checkmark$ & $\checkmark$ & $\checkmark$ & $\checkmark$ \\
$\mathrm{R}^{2}$ & $\checkmark$ & $\checkmark$ & $\checkmark$ & $\checkmark$ & $\checkmark$ \\
Obs. & .92 & .94 & .96 & .94 & .98 \\
\hline
\end{tabular}

Note-Standard errors are reported in parenthesis below the coefficients. ${ }^{*}$ indicates significance at the $10 \%$ level, ${ }^{* *}$ at $5 \%$ and ${ }^{* * *}$ at the $1 \%$ level. Standard errors are clustered by state. Sample sizes vary slightly because we do not observe migrants in all state-year cells when the sample is stratified by arrival intervals. Non-sanctuary states are all states excluding California, Texas, New York, Florida, and New Jersey.

\section{Competing interests}

The IZA Journal of Migration is committed to the IZA Guiding Principles of Research Integrity. The author declares that he has observed these principles.

\section{Acknowledgements}

I would like to thank the editor and referees for their thoughtful comments. I am grateful to Peter Kuhn, Kelly Bedard, Olivier Deschenes, Hani Mansour, Daniel I. Rees, Steve Trejo, the participants of the Southern California Conference in Applied Microeconomics, and the participants of the All-California Labor Economics Conference for their helpful input. All errors are my own.

Responsible editor: Denis Fougère

Received: 15 February 2013 Accepted: 18 July 2013

Published: 3 September 2013

\section{References}

Allegretto S, Dube A, Reich M (2010) Spatial Heterogeneity and minimum wage: employments estimates for teens using cross-state commuting zones. Institute for Research on Labor and Employment, University of California Berkeley. http://www.irle.berkeley.edu/workingpapers/181-09.pdf. Accessed 5 Jul 2013

Allegretto S, Dube A, Reich M (2011) Do Minimum Wages Really Reduce Teen Employment? Accounting for Heterogeneity and Selectivity in State Panel Data. Ind Relat 50(2): 205-240

Bailey MA (2005) Welfare and multifaceted decision to move. Am Pol Sci Rev 99(1): 125-135

Borjas GJ (1999) Immigration and welfare magnets. J Labor Econ 17(4): 607-637

Borjas GJ, Hilton L (1996) Immigration and the welfare state: immigrant participation in means-tested entitlement programs. Q J Econ 111(2): 575-604

Cadena BC (2012) Immigrants as labor market arbitrageurs: evidence from the minimum wage. Department of Economics, University of Colorado Boulder. http://spot.colorado.edu/ cadenab/Research_files/ immig_minwage_jun2012.pdf. Accessed 5 Jul 2013

Card D (1992a) Using regional variation in wages to measure the effects of the federal minimum wage. Ind Labor Relat Rev 46(1): 22-37

Card D (1992b) Do minimum wages reduce employment? A case study of California, 1987-89. Ind Labor Relat Rev 46(1): $38-54$

Card D, Krueger AB (1994) Minimum wages and employment: a case study of the fast-food industry in New Jersey and Pennsylvania. Am Econ Rev 84(4): 772-793

Cebula RJ (1979) The determinants of human migration, Lexington, MA: Lexington Books

Deepti G, Lang K (2009) Social Ties and the Job Search of Recent Immigrants, NBER Working Papers 15186, National Bureau of Economic Research, Inc.

DiNardo J, Fortin NM, Lemieux T (1996) Labor market institutions and the distribution of wages, 1973-1992: a semiparametric approach. Econometrica 64(5): 1001-1044

Dube A, Lester TW, Reich M (2010) Minimum wage effects across state borders: estimates using contiguous counties. Rev Econ Stat 92(4): 945-96 
Edmark K (2009) Migration effects of welfare reform. Scand J Econ 111(3): 511-526

Fiva JH (2009) Does welfare policy affect residential choices? An empirical investigation accounting for policy endogeneity. J Public Econ 93(3-4): 529-540

Gelbach J (2004) Migration, the lifecycle, and state benefits: how low is the bottom? J Pol Econ 112(5): 1091-1131

Giulietti C (forthcoming) Is the Minimum Wage a Pull Factor for Immigrants? Ind Labor Relat Rev

Harris JR, Todaro MP (1970) Migration, unemployment and development: A two-sector analysis. Am Econ Rev 60(1): 126-142

Katz LF, Krueger AB (1992) The effect of the minimum wage on the fast-food industry. Ind Labor Relat Rev 46(1): 6-21

Neumark D, Wascher W (2000) Minimum wages and employment: a case study of the fast-food industry in New Jersey and Pennsylvania: comment. Am Econ Rev 90(5): 1362-1396

Kennan J, Walker JR (2010) Wage, welfare, and individual migration. J Econometrics 156(1): 229-238

Lee DS (1999) Wage Inequality in the United States During the 1980s: Rising Dispersion or Falling Minimum Wage? Quarterly J Econ 114(3): 977-1023

Lemos S (2005) Political variables as instruments for the minimum wage. Contributions to Economic Analysis \& Policy 4(1) article 16

Levine PB, Zimmerman DJ (1999) An empirical analysis of the welfare magnet debate using the NLSY. J Popul Econ 12(3): 391-409

Lubotsky D (2007) Chutes and ladders? A longitudinal analysis of immigrant earnings. J Pol Econ 115(5): 820-867

McKinnish T (2005) Importing the Poor Welfare Magnetism and Cross-Border Welfare Migration. J Hum Resour 40(1): $57-76$

McKinnish T (2007) Welfare-Induced Migration at State Borders: New Evidence from Micro-Data. J Public Econ 91(3-4): 437-450

Meyer B (2000) Do the poor move to receive higher welfare benefits? Department of Economics and Institute for Policy Research, Northwestern University. http://harrisschool.uchicago.edu/directory/faculty/bruce_meyer. Accessed $5 \mathrm{Jul}$ 2013

Moffitt R (1992) Incentive effects of the, U.S. welfare system: a review. J Econ Lit 30(1): 1-61

Munshi K (2003) Networks in the Modern Economy: Mexican Migrants in the U. S. Labor Market. Quarterly J Econ 118(2): 549-599

Orrenius PM, Zavodny M (2005) Self-selection among undocumented immigrants from Mexico. J Dev Econ 78(1): 215-240 Orrenius PM, Zavodny M (2008) The effect of minimum wages on immigrants' employment and earnings. Ind Labor Relat Rev 61(4): 544-563

Orrenius PM, Zavodny M, Lukens L (2008) Why stop there? Mexican migration to the U.S border region. Federal Reserve Bank of Dallas. http://www.dallasfed.org/assets/documents/research/papers/2008/wp0803.pdf. Accessed 5 Jul 2013 Peri G, Sparber C (2009) Task specialization, immigration and wages. Am Econ J: Appl Econ 1(3): 135-169

doi:10.1186/2193-9039-2-17

Cite this article as: Boffy-Ramirez: Minimum wages, earnings, and migration. IZA Journal of Migration 2013 2:17.

\section{Submit your manuscript to a SpringerOpen ${ }^{\odot}$ journal and benefit from:}

- Convenient online submission

Rigorous peer review

- Immediate publication on acceptance

- Open access: articles freely available online

- High visibility within the field

- Retaining the copyright to your article

Submit your next manuscript at $\gg$ springeropen.com 